This is an electronic reprint of the original article. This reprint may differ from the original in pagination and typographic detail.

Author(s): Koskinen-Koivisto, Eerika

Title: Hyvistä tyypeistä tietoisuustaitajiin : kriittisiä näkökulmia palvelutalouden työruumiisiin kohdistamiin vaatimuksiin

Year: $\quad 2017$

Version:

Please cite the original version:

Koskinen-Koivisto, E. (2017). Hyvistä tyypeistä tietoisuustaitajiin : kriittisiä näkökulmia palvelutalouden työruumiisiin kohdistamiin vaatimuksiin. Elore, 24(1). https://doi.org/10.30666/elore.79289

All material supplied via JYX is protected by copyright and other intellectual property rights, and duplication or sale of all or part of any of the repository collections is not permitted, except that material may be duplicated by you for your research use or educational purposes in electronic or print form. You must obtain permission for any other use. Electronic or print copies may not be offered, whether for sale or otherwise to anyone who is not an authorised user. 


\title{
Hyvistä tyypeistä tietoisuustaitajiin - kriittisiä näkökulmia palvelutalouden työruumiisiin kohdistamiin vaatimuksiin
}

\author{
Parviainen, Jaana, Taina Kinnunen \& Ilmari Kortelainen (toim.) 2016: \\ Ruumiillisuus ja työelämä. Työruumis jälkiteollisessa taloudessa. Tampere: \\ Vastapaino. 254 sivua.
}

\section{Eerika Koskinen-Koivisto}

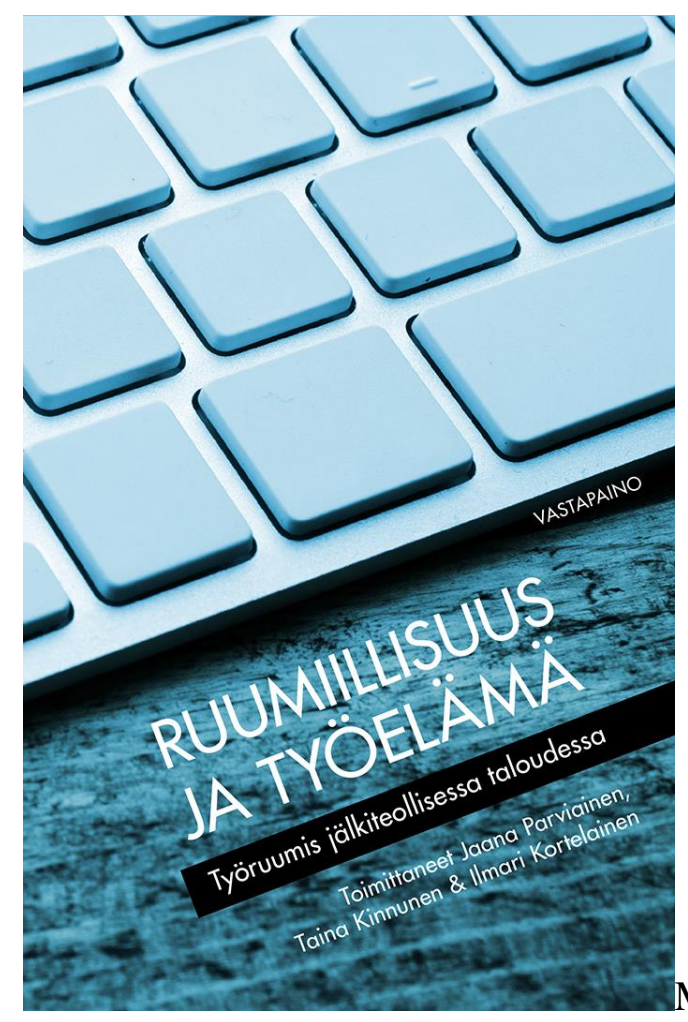

Millaisia työntekijöitä nykytyöelämä haluaa? Entä

miten ihannetyöntekijäksi tullaan? Artikkelikokoelmassa Ruumiillisuus ja työelämä.

Työruumis jälkiteollisessa taloudessa (2016) tarkastellaan, millaisia ajatusmalleja ja ideologisia kytkentöjä työntekijöiden ominaisuuksiin kohdistuvien, sinänsä myönteisten ja näennäisen viattomien vaatimusten takana piilee. Tekstien lähtökohtana on, että henkilökohtaiset ruumiillisiin eleisiin, tekoihin ja fyysisiin piirteisiin perustuvat ominaisuudet, kuten asenne ja vuorovaikutustaidot, ovat suoraan sidoksissa työntekijän haluttavuuteen palvelutalouden työmarkkinoilla. Palvelutalouden artikkelikokoelman toimittajat Jaana Parviainen, Taina Kinnunen ja Ilmari Kortelainen määrittelevät kapitalismin uudeksi vaiheeksi, jossa inhimilliset kyvyt on valjastettu uudella tavalla tuottamaan varallisuutta ja lisäarvoa. Palvelutalous nojaa uusliberalistiseen ihmiskäsitykseen, jossa kaikilla ihmisillä on samanlaiset mahdollisuudet menestykseen. Uusliberalistien mukaan yksilöiden toiminnalle ei ole tarvetta luoda institutionaalisia rajoituksia, vaan he uskovat yksilöiden itseohjautuvuuteen ja vapauteen. Artikkelikokoelman kirjoittajat muistuttavat ja osoittavat erilaisten tapausten perusteella, että yksilöiden ruumiilliset piirteet ja eleet ovat 
kuitenkin pitkälti sosiaalisten verkostojen, kulttuurisen pääoman, luokkataustan, etnisten piirteiden ja uskonnollisten vakaumusten muokkaamia ja näin ollen sidoksissa yhteiskunnalliseen asemaan ja taustaan.

Kokoelman toimittajat näkevät, että uuden palvelutalouden taustalla on merkittävä ja monimutkainen talouden ja kulttuurin murros, joka on yhteydessä globalisaatiokehitykseen ja digitalisaatioon. Murroksen myötä monenlaisia työtehtäviä on alettu kutsumaan palveluiksi samalla, kun ne on ulkoistettu. Näin ollen lähes kaikista ammateista on tullut palveluammatteja, jotka edellyttävät tietynlaista asennetta ja valmiutta tuottaa palvelukonsepteja ja elämyksiä pelkän työtehtävien suorittamisen sijaan.

Artikkelikokoelmassa kysytään, millaisia vaikutuksia palvelutalouteen siirtymisellä on työntekijöille, työorganisaatioille ja johtamiselle. Entä millainen tausta, valmiudet ja ruumiilliset piirteet synnyttävät palvelutalouden menestyjiä?

Teoksen kirjoittajat ovat yhteiskuntatieteiden, filosofian, kulttuuriantropologian ja kasvatustieteen tutkijoita. Artikkelit liikkuvat emotionaaliseen ja esteettiseen työhön, työorganisaation ruumiillisuuteen ja vallankäyttöön sekä affekteihin ja ruumiidenvälisyyteen liittyvien teoretisointien ympärillä. Nämä eri tieteenalojen tarjoamat lähestymistavat ja teoreettiset näkökulmat tuottavat monipuolisen kuvan nykytyöelämän vaatimuksista ja työntekijää sopivaksi muokkaavista teknologioista. Esittelen artikkelikokoelman keskeisten lukujen sisältöjä valikoimieni artikkeleiden valossa.

\section{Oikeanlainen ruumiillinen pääoma}

Yksi keskeisimmistä nykytyöelämää leimaavista "oikeanlaisen" asenteen ilmentymistä on yrittäjyys. Filosofi Lauri Lahikaisen ja kasvatustieteilijä Esko Harnin artikkeli itsen yrittäjyydestä ontologisena ja eettisenä ihmiskuvana on sijoitettu teoksen ensimmäiseen, myös yleisen johdannon sisältävään "Työruumis palvelutaloudessa" -lukuun. Tekstissä itsen yrittäjyyden nähdään kumpuavan possessiivisesta individualismista ja ruumiin sitomisesta pääoman logiikkaan, ja artikkeli yhdistyy suoraan toisen luvun ruumiillisen pääoman muotojen pohdintaan. Itsensä yrittäjä parantaa työmarkkina-asemaansa investoimalla itseen ja inhimilliseen pääomaan, toisen sanoen työstää, muokkaa, tuottaa ja brändää itseään erilaisin tekniikoin odottamansa tuoton ja hyödyn mukaisesti. Näin itsen yrittäjän vapaus kääntyykin pakoksi oma-aloitteisesti muokata omaa itseään markkinakelpoiseksi.

Toinen usein kuultu määritelmä ihanteellisesta työntekijästä on "hyvä tyyppi", jota kulttuuriantropologi Taina Kinnunen ja filosofi Jaana Parviainen purkavat rekrytointikonsulttien haastatteluihin perustuen. Hyvän tyypin ensivaikutelma on rekrytoijien "perstuntuma" työntekijäkandidaatista, eikä se ole helposti sanallistettavissa. Intuitiivinen tuntuma perustuu moniaistiseen kommunikaatioon, jossa ruumiiden rytmit syntyvät vuorovaikutuksessa toisten kanssa. Kinnunen ja Parviainen näkevät ruumiillisten kohtaamisten taustalla kulttuurisesti muovautuneen ruumiiden affektiivisen hierarkian, jota uusinnetaan tiedostamatta ja jonka yksi ilmentymä on niin sanottu fitness-ideologia, jossa nuoret, kurinalaiset ja treenatut ruumiit asetetaan ihanteeksi. Tutkijat muistuttavatkin, että intuitiivisen arvioinnin taustalla on usein luokkasidonnainen ja sukupuolittunut tottumus, joka ohjaa mieltymyksiin perustuvia valintoja.

Kolmas ruumiillisen pääoman muoto, jolla on merkitystä erityisesti nuorten työntekijöiden työllistyvyydelle, on liikkuvuus, jota yhteiskuntatieteilijä Minna Nikunen lähestyy teknologiana ja tekniikoiden ryppäänä. Liikkuvuutta, sekä kokemusta siitä ja valmiutta 
siihen, tarjotaan väylänä menestykseen. Nikunen kuitenkin kiinnittää huomioita liikkuvuusvaatimuksen eriarvoisuuteen: vaatimus perheenperustamisen lykkäämisestä ja turvaverkostosta irtautumisesta vaikeuttaa erityisesti nuorten perheellisten naisten työllistymistä koulutusta vastaaviin ja arvostettuihin kansainvälisiin asiantuntijatehtäviin, joiden ajatellaan olevan menestyneiden korkeakoulutettujen eurooppalaisten nuorten tavoitteena. Tehtävien edellyttämään menestyvän eurooppalaisnuoren habitukseen kuuluvat kielitaito, aktiivisuus ja kulttuurienvälinen osaaminen. Tämä nähdään ihanteena, jolle vastakkaisena pidetään työväenluokkaisten ja maaseudulla asuvien nuorten haluttomuutta jättää kotiseutunsa ja tutut ympyrät. Kodin piiriin jääminen näyttäytyy kypsymättömänä tekona, jonkinlaisena väärinymmärryksenä. Nikunen kritisoikin uusliberalistien teesiä siitä, että vain toiminta ja saavutukset merkitsevät; myös liikkuvuuden kohdalla sukupuolella ja luokalla on väliä.

\section{Ammatillinen ja työhön uponnut ruumis}

Ruumiillisuuden voidaan nähdä olevan kaiken ammattilaisuuden ytimessä, myös ammattien, joissa ei olla välittömässä kosketuksessa toiseen ruumiiseen, vaan tuotetaan kauneuteen liittyviä vinkkejä ja välitetään toisten kokemuksia tekstin muodossa, kuten toimittajan työssä. Organisaatioiden ja johtamisen tutkija Niina Kivisen analyysi tytöille suunnattua aikakauslehteä tekevistä media-ammattilaisista ja heidän ristiriitaisesta työruumiistaan nostaa esiin "ruumiittomuuden" ja etääntymisen ainoana oikeana mutta julkilausumattomana toimintamallina.

Naistutkija/sukupuolentutkija Päivi Korvajärvi puolestaan tarkastelee kosmetologin työtä emotionaalisen työn ja affektien näkökulmasta. Niin kauneudenhoidossa kuin hoivatyössä, jotka molemmat ovat naisvaltaisia aloja, on kyse työn elävästä suhteesta ihmisruumiiden välillä. Tällaisessa emotionaalisessa työssä ja ruumiillisuutta käsittelevässä työssä (body work) tunteet ovat osa tietotaitoa ja toimivat läsnäolon ja kosketuksen ohella tärkeinä työvälineinä.

Sekä kentästään etääntyvien toimittajien että emotionaalista työtä tekevien ruumiiden odotetaan säätelevän osallistumistaan ja reaktioitaan ruumiin ja mielen tasolla. Erityisesti mielenhallintaan perustuvia tekniikoita tarjotaan nykyään lääkkeeksi myös arkielämän ja työn hektisyyteen väsyneille. Aikuiskasvatuslehden artikkelipalkinnon vuonna 2017 elinikäisen oppimisen kritiikillään saanut kasvatustieteilijä Antti Saari kirjoittaa tietoisuustaidoista (mindfullness) psykotekniikkana, joka leviää nopeasti niin työelämän hallinnassa kuin kasvatuksen ja koulutuksen maailmassa. Saari näkee tietoisuustaidot osana sosiologi Anthony Giddensin (1991) muotoilemaa jälkimodernin ihmisen yksityiseen elämään leviävää asiantuntijuutta ja refleksiivisyyttä, joka haastaa tutkimaan ja rakentamaan omaa identiteettiään. Saari analysoi erityisesti opettajille tarjottavia tietoisuusharjoituksia ja niiden tavoitteita sekä ohjeistuksissa ilmeneviä kaksoissidoksia eli toinen toisensa kumoavia viestejä. Havainnollinen esimerkki tällaisesta ristiriitaisuudesta löytyy tietoisuusharjoitusten yksityiskohtaisista ohjeista kurinalaisten ruumiillisten asentojen ja hengitysrytmien soveltamisesta ja tämän kurinalaisuuden tuottamasta henkisestä tyyneydestä, tarkkaavaisuudesta ja spontaanista läsnäolosta. Ja edelleen, samalla kun opettaja ohjaa oppilaitaan kohti kokonaisvaltaista hyvinvointia, voidaan sen tuloksia ja mukanaan tuomaa tuloksellisuutta mitata määrällisesti.

\section{Toisin toimimisen ja onnellisen työelämän mahdollisuudet}


Kirjan artikkeleissa kiinnitetään huomiota tärkeisiin näkökulmiin kuten yksilön vastuuttamiseen, työelämän edelleenkin piilossa oleviin ja julkilausumattomiin sukupuolittuneisiin käytäntöihin ja eriarvoistumiseen. Jäin kuitenkin miettimään, antavatko filosofian, yhteiskuntatieteiden ja kulttuurintutkimuksen teoriat ja empiiriset analyysit liian pessimistisen kuvan työelämästä ja itsensä toteuttamisen mahdollisuuksista. Onko uusliberalismin läpäisemille vaatimuksille varteenotettavia haastajia työelämässä? Kenellä jos ylipäätään kellään - on mahdollisuus toimia toisin? Ja onko työn näkeminen vapautumisen ja itsensä toteutuksen kenttänä aina kapitalistisen ajattelun läpäisemää?

Sosiologit Pasi Pyöriä ja Satu Ojala (2016) ovat tutkineet työelämän koettua epävarmuutta työolotutkimusten eli laajojen kyselyaineistojen kautta ja argumentoivat aineistoonsa perustuen, että suomalainen työelämä ei ainakaan sen valossa ole erityisesti kurjistunut eivätkä epätyypilliset ja määräaikaiset työsuhteet lisääntyneet. He kritisoivatkin suomalaista työelämään liittyvää tutkimusta keskittymisestä suppeahkoihin haastattelututkimuksiin sekä tavasta soveltaa laajaa prekarisaatio-teesiä, jonka mukaan prekarisaatio on yhteiskunnan läpileikkaavan talouspoliittisen ideologian eli uusliberalismin tuottamaa. Pyöriän ja Ojalan mukaan tutkimuksen orientaatio olisi erilainen, jos siinä keskityttäisiin työmarkkinoiden rakenteisiin ja olosuhteisiin sekä laajempiin tutkimusaineistoihin.

Myös viime vuosikymmeninä työelämän tutkimuksessa vaikuttaneen positiivisen käänteen myötä tutkijat ovat alkaneet kysyä, mikä työntekijöitä kannattelee ja motivoi ja tekee heidän työstään mielekkään myös silloin, kun ulkoinen toimintaympäristö ja työt ovat muutoksessa. Tämä positiivisen psykologian innoittama käänne on tuonut tutkimukseen uusia käsitteitä ja näkökulmia kuten työn imu (esim. Hakala 2009) ja kestävä työ (esim. Kira 2003; Kasvio 2014), joiden kautta nykytyöelämä ja sen muutokset näyttäytyvät myös onnellisuuden, mahdollisuuksien ja hyvinvoinnin näkökulmasta. Muuttaisiko sosiologisen ja psykologisen tutkimuksen tuominen mukaan kulttuurintutkimuksen rinnalle kuvaa työtä tekevistä ruumiista? Työruumiiden tarkastelu kokonaisvaltaisen hyvinvoinnin, voimavarojen ja arkisen toiminnan näkökulmasta voisi tuottaa kiinnostavia uusia avauksia. Ruumiillisten käytäntöjen tarkastelu etätyössä tai esimerkiksi maalle muuttaneiden itsensä työllistäjien arjessa sekä ruumiiden yhteinen toiminta jakamistaloudessa voisivat olla esimerkkejä tutkimusaiheista, joiden kautta talouden ja kulttuurin kytkökset avautuisivat alisteisen suhteen sijaan toimijuuden näkökulmasta.

\section{Kirjallisuus}

Hakanen, Jari 2009: Työn iтиа, tuottavuutta ja kukoistavia työpaikkoja? Kohti laadukasta työelämää. Helsinki: Työsuojelurahasto.

Kasvio, Antti 2014: Kestävä työ ja hyvä elämä. Tampere: Vastapaino.

Kira, Mari 2003: From Good Work to Sustainable Development. Human resources consumption and regeneration in the post-bureaucratic working life. Stockholm: Kungl Tekniska Högskolan.

Pyöriä, Pasi \& Ojala, Satu 2016: Prekaarin palkkatyön yleisyys: liioitellaanko työn epävarmuutta? - Sosiologia 53 (1), 45-63. 
Filosofian tohtori Eerika Koskinen-Koivisto työskentelee tutkijatohtorina Jyväskylän yliopistossa. Hän on kiinnostunut työelämän kestävyydestä ja työelämään liittyvästä kerronnasta. 